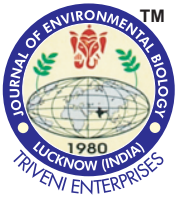

\title{
Temporal change of land use in the Protection Basin of Tahtalı Dam (1990-2015), (Izmir, Turkey)
}

\section{Authors Info}

A.E. Gülersoy ${ }^{1 *}$ and M.A. Çelik ${ }^{2}$ ${ }^{1}$ Department of Social Studies, Buca Faculty of Education, Dokuz Eylul University, Izmir, 35150, Turkey

${ }^{2}$ Department of Geography, Faculty of Arts and Sciences, Kilis 7 Aralik University, Kilis 79000, Turkey

*Corresponding Author Email : gulersoy74@gmail.com

Key words

Protection basin,

Temporal change,

Tahtali Dam

Publication Info

Paper received : 18.10 .2016

Revised received : 20.06.2017

Accepted : 27.06.2017

\section{Abstract}

Aim: The present study was carried out evaluate the temporal changes of land use in the Protection Basin of Tahtalı Dam in terms of sustainable use of natural resources through 1990 and 2015.

Methodology: In the study, Lands at TM satellite image dated 06.08 .1990 with spatial resolution of $15 \mathrm{~km}$ and Lands at OLI satellite image dated 06.08.2015 were used in order to determine conditions of land use through the year 1990 and 2015.

Results: Despite a $12 \%$ decrease in cropland areas and $1.4 \%$ in forests-maquis-garrigues, a $119 \%$ increase in water surfaces, $34 \%$ in residential areas and $17539 \%$ in greenhouse areas occurred through 1990-2015 in the Protection Basin of Tahtalı Dam. There was a mismatch between the land capability classes and their use. The said situation had resulted in some disadvantages. As a matter of fact, severe erosion which was seen at the part of $54 \%$ of the basin has the impact on lands which are inclined and devoid of natural vegetation cover. There was an increase stemming from domestic and industrial wastes in parameters for chemical oxygen demand and biological oxygen demand in the basin. As a result of land degradation and erosion, nearly $25 \%$ of lands of the basin have become unusable losing their natural characteristics.

Interpretation: In order to prevent degradation, erosion and pollution, soils should be used according to the land capability classes. Cooperativation should be encouraged for a continuous and planned marketing in the basin, and alternative sustainable economic activities should be promoted. Furthermore, basin protection activities should be formed by an interdisciplinary understanding and collaboration should be established among local people.

\begin{tabular}{|c|c|c|c|c|c|c|}
\hline & \multicolumn{4}{|c|}{ Tahtali Dam Protection Basin } & & \\
\hline & \multirow{2}{*}{\multicolumn{4}{|c|}{$\frac{\downarrow}{\text { Temporal change of land use (1990-2015 }}$}} & & \\
\hline & $\begin{array}{c}\text { Temporal change of land use (1990-2015 } \\
\downarrow\end{array}$ & & & & & \\
\hline Years & \multicolumn{2}{|c|}{1990} & \multicolumn{2}{|c|}{2015} & \multicolumn{2}{|c|}{ Change (1990-2015) } \\
\hline Land classes & $\mathrm{Ha}$ & $\%$ & $\mathrm{Ha}$ & $\%$ & $\mathrm{Ha}$ & $\%$ \\
\hline Forest & $41,182.5$ & 63.75 & $40,594.64$ & 6.284 & -587.86 & -1.4 \\
\hline Arable land & $20,930.4$ & 32.4 & $18,520.82$ & 28.67 & $-2,409.58$ & -11.5 \\
\hline Greenhouse & 8.46 & 0 & $1,492.26$ & 2.31 & $1,483.8$ & 17,539 \\
\hline Settlement & $1,698.98$ & 2.63 & $2,267.46$ & 3.51 & 568.48 & 33.5 \\
\hline Water surfaces & 788.12 & 1.22 & 1.724 .82 & 2.67 & 936.7 & 118.9 \\
\hline
\end{tabular}

As a result of land degradation and erosion, nearly $25 \%$ of lands of the basin have become unusable losing their natural characteristics. Residential waste, intensive use of pesticides-chemical fertilizers, and large industrial facilities pollute dam water and cause land degradation.

$\downarrow$

The basin protection activities should be formed by an interdisciplinary understanding and collaboration should be established among local people. 


\section{Introduction}

Improvement attempts of developing countries such as Turkey in particular as well as increasing population and needs within natural environment-human activities are ever increasing pressure on sources of natural environment (Öztürk et al., 2002; Goudie, 2006; Atalay and Efe, 2010; Efe et al., 2012; Efe et al. 2013;Gülersoy et al., 2015; Gülersoy and Çelik, 2015). Plain and middle inclined areas suitable for agriculture make up $21 \%$ of the farm land in Turkey. Within this scope, it is understood that areas such as the Protection Basin of Tahtalı Dam (the percentage of plain and middle-inclined lands suitable for agriculture, 36\%) have an important role for the country's economy in terms of agricultural and water demand. Tahtalı Dam Protection Basin meets $34 \%$ of lzmir's water demand.

Although dams are largely regarded as environmentfriendly and renewable resources, they lead to shrinkage of agricultural lands, siltation, ecosystem problems, and migration (Strahlerand Strahler, 2006; Sönmez, 2012). Despite the downsides, dams are built to meet the demand for drinkingpotable water by the growing number of people living especially in cities. It is a fact that the economic lives of dams are likely to come to an end in less than 100 years (Strahlerand Strahler, 2006). Preventing siltation and pollution of dams is only possible through the engagement of local population in basin protection efforts and the employment of a suitable land use method (Ghimire and Pimbert 1997;Ay, 2001; Manyari and Carvalho, 2007).

\section{Materials and Methods}

Purpose of this study is to evaluate temporal changes of land use in the Protection Basin of Tahtalı Dam in terms of sustainable use of natural resources through 1990 and 2015. In the study, we used Lands at TM satellite image dated 06.08.1990 with spatial resolution of $15 \mathrm{~km}$ and Lands at OLI satellite image dated 06.08 .2015 in order to determine conditions of land use through the years of 1990 and 2015. Controlled classification was applied to satellite images in Erdas Imagine software. The images which were classified by applying "Maximum Similarity Method" were composed of 150 classes at first. Later, the recorded images were reduced to $4^{\text {th }}$ class on satellite image of the year 1990 and to $5^{\text {th }}$ class on satellite image of the year 2015, and then land use maps of the Protection Basin of Tahtalı Dam for the years 1990 and 2015 were created. These classes were determined as forest, cropland (field), greenhouse (only for 2015), residential areas and water surfaces. In the study, accuracy analyses were performed on the data produced by "maximum similarity method" from Landsat TM satellite images of the years 1990 and 2015. Accordingly, while accuracy rate of the image belonging to 1990 is 0.85 by kappa coefficient, that of 2015 is also 0.85 (Fig. 2). These obtained data are an indication of the fact that classification is at a level which may be deemed valid (Gülersoy, 2013).

Study area: Located at the central part of the Coastal Aegean Subdivision in the Aegean Region of the Western Turkey, the Protection Basin of Tahtalı Dam is in between highlands where western and southern slopes of Mount Nif (1510 m.) on the
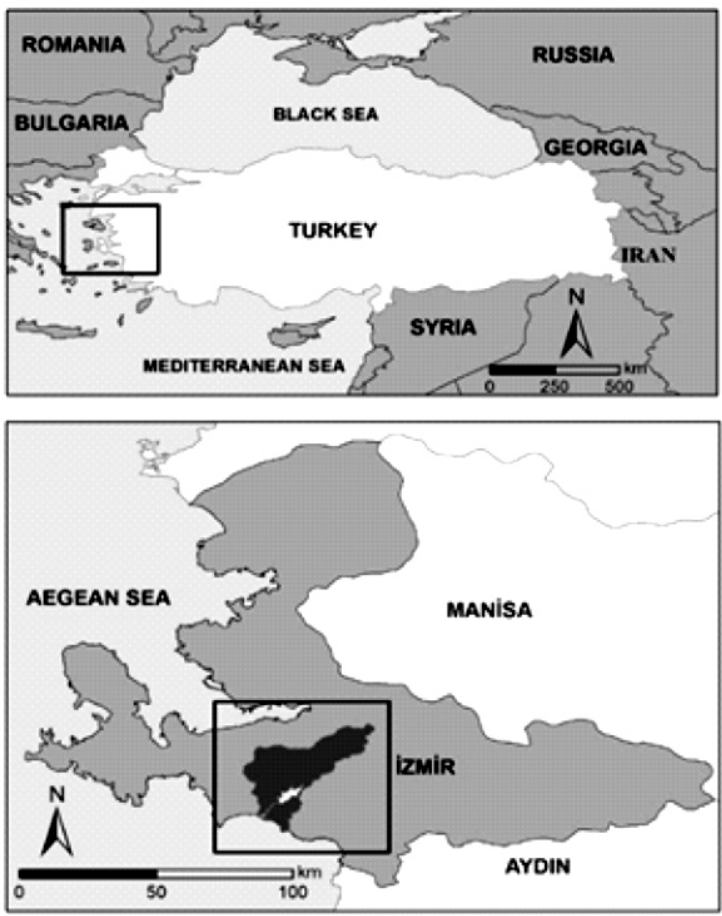

Fig. 1 : Location map for the Protection Basin of Tahtalı Dam

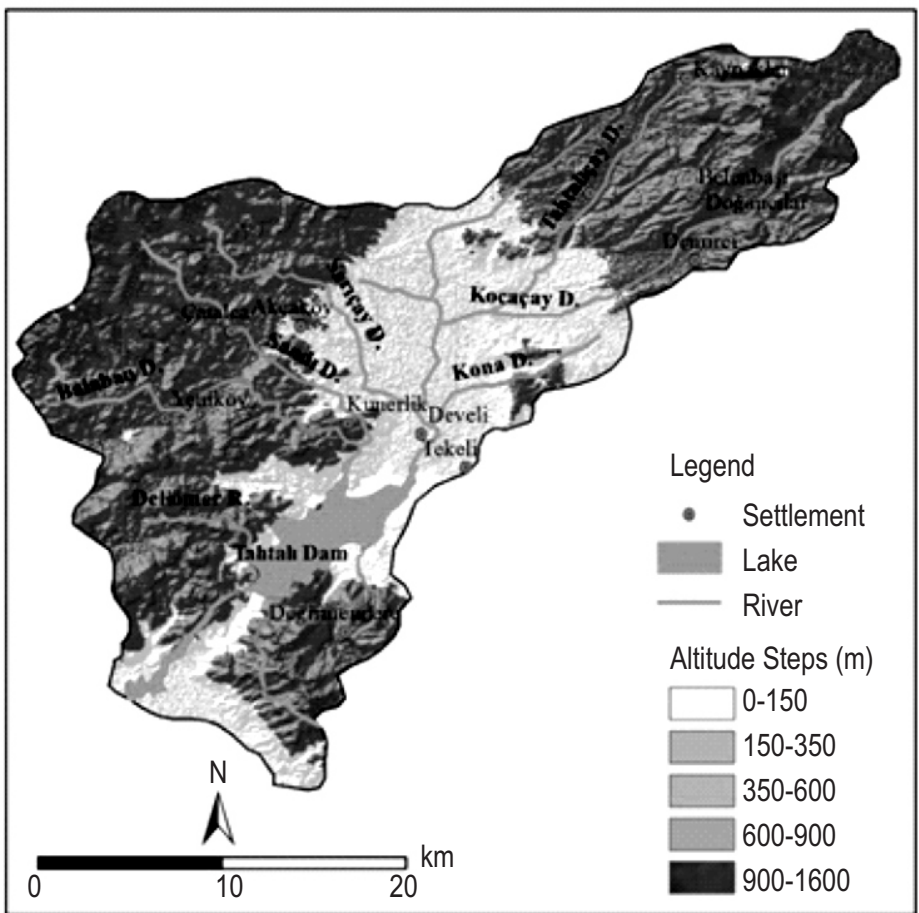

\begin{tabular}{l} 
Settlement \\
Lake \\
\hline River \\
Altitude Steps (m) \\
$\square-150$ \\
$\square$ 150-350 \\
$350-600$ \\
$600-900$ \\
$\square 00-1600$ \\
\hline$\square$
\end{tabular}

Journal of Environmental Biology, Special issue, September 2017 

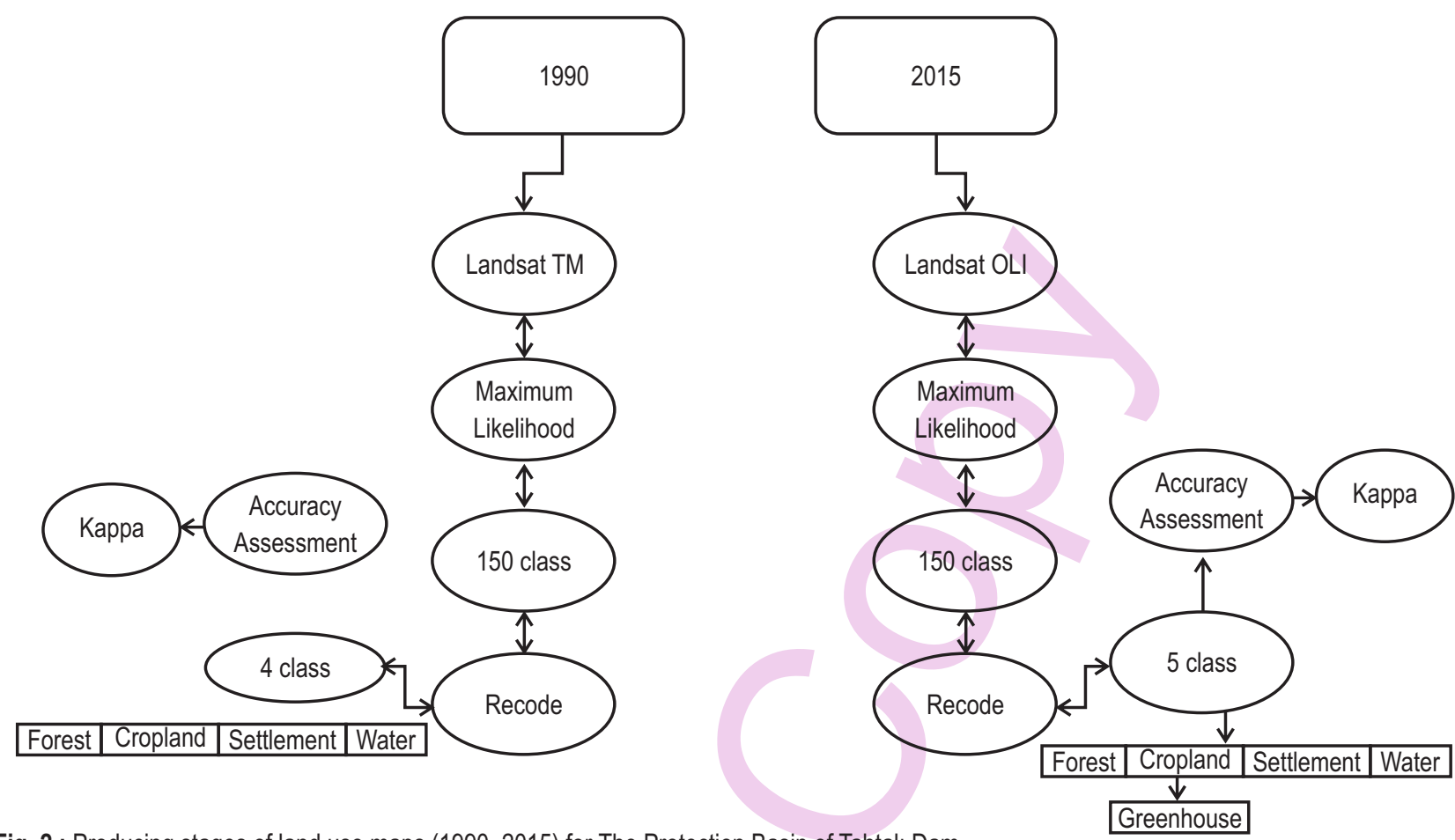

Fig. 2 : Producing stages of land use maps $(1990,2015)$ for The Protection Basin of Tahtalı Dam

northeast connects with Buca ridges, and Çatalkaya slopes on the west, Gümüldür-Tahtalı strait on the south and Little Meander (Küçük Menderes) plains on the east. While $69 \%$ of the basin remains within the borders of Izmir province, this big part is located within the administrative areas of Menderes district; $19 \%$ within Buca; 4.4\% within Gaziemir; 3\% within Kemalpaşa; 2.4\% within Torbalı; $2 \%$ within Karabağlar; and $0.2 \%$ within Seferihisar. The basin covers an area of $646 \mathrm{~km}^{2}$, and is drained by Tahtalı Streamlet and its tributaries (Fig. 1).

\section{Results and Discussion}

Land use (1990): In 1990, 64\% of lands in the Protection Basin of Tahtalı Dam constituted the forest areas, 32\% agricultural areas, $3 \%$ residential areas, and $1 \%$ of water surfaces (Table 1 ; Fig. 3 ). Maquis and garrigue plant formationsconstitute $30 \%$ of the forest areas. Seventy six per cent and $24 \%$ of agricultural areas were used as dry farming area and irrigated farming area, respectively. In the research field, the meadow-pasture areas occupying a small space (2\%) increased the pressure on forest-maquis. In the $3 \%$ area of the basin, residential, tourism, industry and mining activities were carried out. Together with Tahtalı Streamlet and its tributaries as well as ponds on them, the lower part by which the dam had begun to retain the water (construction started in 1986) constituted water surfaces which form $1 \%$ of the area.

Forest areas (62.8\%) in the Protection Basin of Tahtalı Dam showed distribution on mountainous-hilly areas surrounding the base of the basin over $6^{\text {th }}$ and $7^{\text {th }}$ class lands in general on the inclined areas (incline rate is 10-15\%) where metamorphic rocks (marble, schist), flysch, limestone, marl, and vulcanite had a wide coverage. In the basin, maquis-garrigues in residues, which was the result of the destruction, had an extensive coverage over $6^{\text {th }}$ and $7^{\text {th }}$ class lands. Seventy six per cent of agricultural lands were used as dry farming area (grain, olive, vineyards, and etc.). Dry farming areas showed distribution in almost every part of the basin over $1^{\text {st }}, 2^{\text {nd }}, 3^{\text {rd }}$, and $7^{\text {th }}$ class lands. In 1990 , irrigated farming activities were carried out in the $24 \%$ of agricultural areas. Irrigated farming activities being intense over $1^{\text {st }}, 2^{\text {nd }}, 3^{\text {rd }}$, and $4^{\text {th }}$ class lands were performed on the base of the basin and alongvalley where incline value was less than normal (the incline was 0$5 \%$ ). Irrigated farming areas showed distribution around Tahtalı Streamlet and its tributaries, and around Cumaovası. Irrigated farming activities were based largely on underground watering. In the study area in 1990, production of grain (36\%) and grape $(26 \%)$ were frequent. Olive $(14 \%)$ has been a preferred agricultural crop in the basin from past to present. Olive grove areas had a wide coverage on the Neogene sediments, colluvial deposits, and the flysch. Production of tobacco (10\%), vegetables $(6 \%)$ and cotton $(5 \%)$ relatively maintained former importance in the basin (Buca, Gaziemir, Menderes, Torbalı district Agriculture directorates, 1990; Ay, 2001). Greenhouse areas appeared in a quite limited area $(1 \%)$ and agricultural production in these greenhouses was performed to meet the needs of Izmir metropolis. While pasture areas did not have a wide coverage $(2 \%)$ in the basin, deficiency of pasture areas caused forest, maquis areas, and olive groves to be used as the grazing land, 
Table 1:Land use situation in the Protection Basin of Tahtalý Dam (1990)

\begin{tabular}{lll}
\hline Forms of land use & \multicolumn{2}{c}{1990} \\
\cline { 2 - 3 } & ha & $\%$ \\
\hline Forest & $41.182,5$ & 63.75 \\
Arable land & $20.930,4$ & 3.4 \\
Greenhouse & 8,46 & 0 \\
Settlement & $1.698,98$ & 2.63 \\
Water surfaces & 788,12 & 1.22 \\
\hline
\end{tabular}

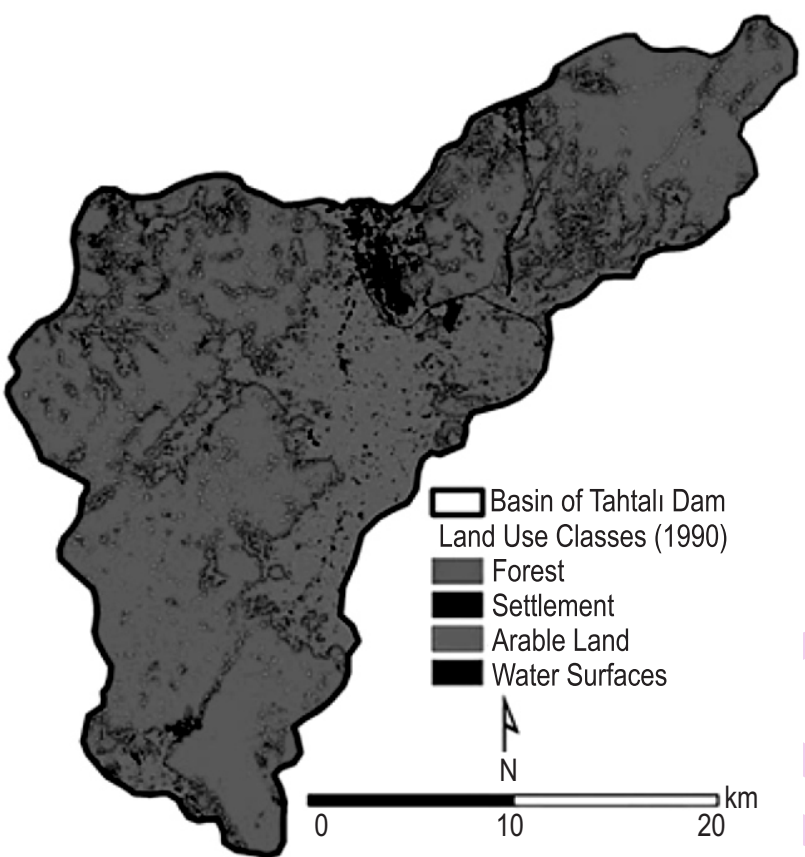

Fig. 3 : Map for land use of the Protection Basin of Tahtali Dam (1990)

and this accelerated land degradation. Pasture areas showed distribution on the sloped areas surrounding the base of the basin, on $7^{\text {th }}$ and $6^{\text {th }}$ class lands which were devoid of trees and underbrush, and on $1^{\text {st }}, 2^{\text {nd }}, 3^{\text {rd }}$ class lands which should be used as agricultural areas. Residential, tourism, industry and mining activities were carried out in the $3 \%$ of the basin. Residential areas appeared over $2^{\text {nd }}, 3^{\text {rd }}, 6^{\text {th }}$ and $7^{\text {th }}$ class lands, in general. In the Protection Basin of Tahtalı Dam where 41.270 people used to live by the year 1990, Menderes (6799 people), Sarnıç (4184 people), Tekeli (2382 people), Bulgurca (2237 people), Değirmendere (2227 people), Görece (2080 people), Kaynaklar (1946 people) and Oğlananası (1935 people) were among the important settlement centers (TÜiK, 1990).

Land use (2015) : In the present day, an important part of lands constitutes the forest-maquis-garrigues(62.8\%) and agricultural areas $(31 \%)$ in terms of usage in the basin. In the basin which is located in the hinterland of Izmir, metropolitan residential areas cover a space $(3.5 \%)$ larger than the average of Turkey (1\%). However, water surfaces constitute $2.7 \%$ of the basin depending on the presence of Tahtalı Dam (Table 2; Fig. 4).
According to the regulation prepared by IZSU (Izmir Water and Sewerage Administration General Directorate) for Tahtalı Dam Basin, in horizontal distance beginning from maximum water level, $0-300 \mathrm{~m}$ was determined as absolute protection area $\left(15 \mathrm{~km}^{2}\right), 300-1000 \mathrm{~m}$ as short-distance protection area $\left(28 \mathrm{~km}^{2}\right), 1000-2000 \mathrm{~m}$ as middle-distance protection area $\left(34 \mathrm{~km}^{2}\right)$, over $2000 \mathrm{~m}$ as long-distance protection area $\left(453 \mathrm{~km}^{2}\right)$, and $0-100 \mathrm{~m}\left(28 \mathrm{~km}^{2}\right)$ as absolute protection area of rivulet (Barış, 2008; iZSU, 2016).

In the research area, dry farming has been performed in the $56 \%$ of agricultural lands. Protection status of the research area has brought dry farming activities (grain, particularly olive) and green housing (organic agriculture/farming) into the forefront. Dry farming areas show distribution in almost every part of the basin over lands of $1^{\text {st }}, 2^{\text {nd }}, 3^{\text {rd }}$, and $4^{\text {th }}$ classes. In the basin, irrigated farming and greenhouse areas (44\%) are getting larger day by day. Irrigated farming activities which are intensively performed over $1^{\text {st }}, 2^{\text {nd }}, 3^{\text {rd }}$, and $4^{\text {th }}$ class lands are being conducted on the base of the basin and along-valley where the incline value is low. In this protection basin, irrigated farming activities are generally based on the underground watering (irrigation). Olivegrove areas (22\% of agricultural areas) appear on the base of the basin and over colluvial and Plio-Quaternary deposits on the sides of the basin, in general. Also in the destroyed forestry area, olive groves, together with the Maquis, could be encountered.

According to the agricultural land use in the Protection Basin of Tahtalı Dam, the first place is taken by cropland (field) areas $(56 \%)$ followed by olive-grove areas $(22 \%)$, planted areas $(10 \%)$, vegetable areas $(7 \%)$, and greenhouse areas $(5 \%)$. Among croplands, wheat, barley $(36 \%)$, corn $(11 \%)$, tobacco $(2 \%)$, cotton (1\%), and forage plants such as Vicia sativa, clover, etc. are at the forefront (Buca, Gaziemir, Menderes, Torbalı district Agriculture directorates, 2015). Olive-grove areas (6\% of the basin and $22 \%$ of agricultural areas) have a wide coverage over Neogene sediments, colluvial deposits and flysch. Among planted areas, agriculture for fruit, vineyard, citrus etc. are at the forefront. Plantation of grapevine and fruit has accelerated in the upper parts of the basin through promoting organic farming during the recent years. As for vegetable fields, production of watermelon, pepper, tomato, artichoke, and melon is important.

Table 2 : Land use situation in the Protection Basin of Tahtalý Dam (2015)

\begin{tabular}{lll}
\hline Forms of land use & \multicolumn{2}{c}{$\mathbf{2 0 1 5}$} \\
\cline { 2 - 3 } & ha & \% \\
\hline Forest & $405.94,64$ & 62.84 \\
Arable land & $18.520,82$ & 28.67 \\
Greenhouse & $1.492,26$ & 2.31 \\
Settlement & $2.267,46$ & 3.51 \\
Water surfaces & $1.724,82$ & 2.67 \\
\hline
\end{tabular}




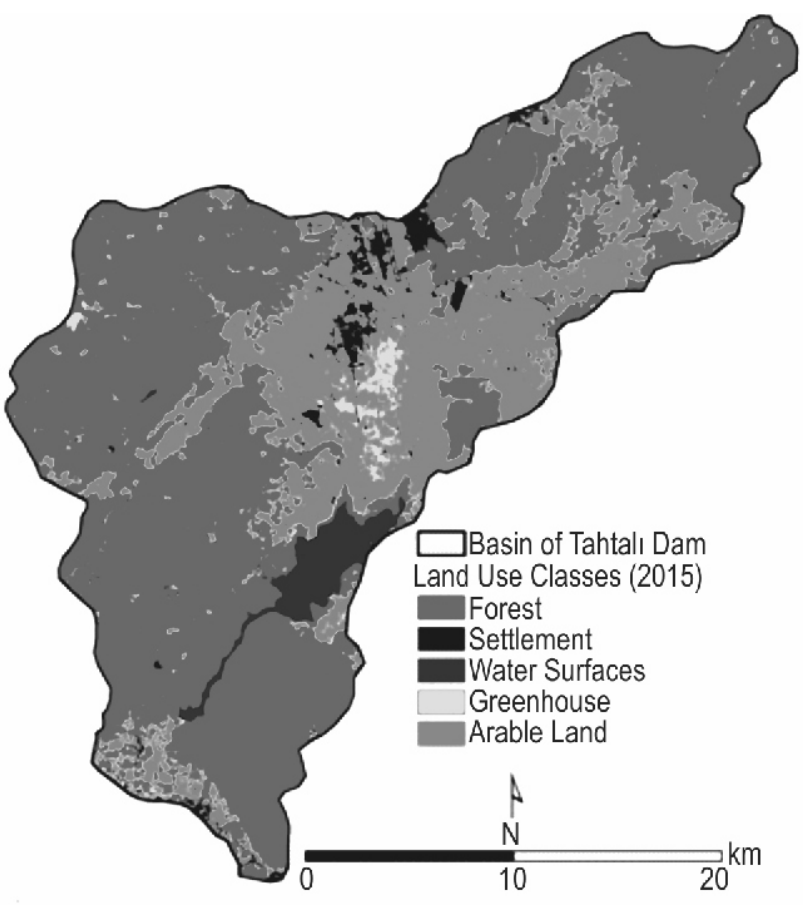

Fig. 4 : Map for land use of the Protection Basin of Tahtalı Dam (2015)

Within the scope of protection activities in the basin, permission for dry farming and ecological agriculture has led to increase green housing activities as well as dry farming in short-, middle-, and long-distance protection areas. In general, cucumber, lettuce, rocket, parsley, tomato, bean, purslane, and cress are grown in the greenhouses which constitute $5 \%$ of agricultural areas in the basin $\left(8.2 \mathrm{~km}^{2}\right)$. As for the cut-flower production, clove and rose are at the forefront.

Forests (62.8\%) in the Protection Basin of Tahtalı Dam show distribution on mountainous-hilly areas surrounding the base of the basin over lands of $6^{\text {th }}$ and $7^{\text {th }}$ classes in general on the inclined areas (incline rate is 10-15\%) where metamorphic rocks (marble, schist), flysch, limestone, marl, and vulcanite have a wide coverage. In the study area, intensive calabrian pine (PinusBrutiaTen.) communities are seen particularly on northand west-facing slopes of mountainous areas, depending on suitable humidity conditions. Generally starting from $250-300 \mathrm{~m}$ altitude in the basin and being able to rise up to $800-900 \mathrm{~m}$ in mountainous-hilly areas, calabrian pines are present in mixed with the Maquis, oak species, and hygrophilous species in inner parts of the valley. Over this altitude, black pines (PinusNigra) start to be seen. Calabrian pines were heavily destructed around residential areas. In these areas where forest areas were turned into maquis-garrigue areas or agricultural lands, bare surfaces devoid of vegetation cover can be encountered (Çukur, 1998). As a matter of fact, calabrian pines are densely seen on high plains at $1000-110 \mathrm{~m}$, on the east slopes of Mount Tekke $(1017 \mathrm{~m})$ which is in the northwestern of the basin out of human impact, and on the west slopes of Mount Nif (1446m) which is in the northeastern of the basin. Around Künerköy Village, stone pines (Pinuspinea) show distribution over volcanic sands (Çukur, 1998). Black pines (Pinusnigra) communities grow and develop at the altitude of 850 $900 \mathrm{~m}$ (on the west slopes of Mount Nif and east slope of Mount Tekke) and can be seen up to the altitudes at which mountain steppes are present. Forestry areas in the Protection Basin of Tahtalı Dam, in general, appear over lands of $7^{\text {th }}(55 \%)$ class and $6^{\text {th }}(25 \%)$ class. In the basin, it is possible to encounter maquisgarrigue areas $(30 \%)$, which is the result of the destruction in pieces. The maquis-garrigue can begin from $150-250 \mathrm{~m}$ in general and go up to $650-700 \mathrm{~m}$. Ryegrass, sandalwood, terebinth, kermes oak, phillyrea, prickly juniper, arbutus, cistus creticus, leaved cistus are encountered up to $500 \mathrm{~m}$, on a relatively less high hilly areas in the northeastern of Menderes and in the other parts of the basin (Koçman, 1989). To come across maquisgarrigue in lands of $7^{\text {th }}$ class which should be the forest area in the basin is striking with regards to dimension of land degradation (Özturk, 1995, 1999; Feoliet al., 2003) in the basin (Fig. 4, 5 and 6).

Pasture areas constitute only $2 \%$ of the basin. They show distribution on the sloped areas surrounding the base of the basin, on $6^{\text {th }}$ and $7^{\text {th }}$ class lands which are devoid of tree and underbrush, and on $1^{\text {st }}, 2^{\text {nd }}, 3^{\text {rd }}$ class lands which should be used as agricultural area. In the areas which should be covered with absolute vegetation and the incline has exceeded $10 \%$, excessive and early grazing has caused erosion to aggravate. There is no compatibility between pasture areas and existing animal presence in the basin. Deficiency of pasture areas has caused forest, maquis areas and olive groves to be used as the grazing land, and this has accelerated land degradation (Fig. 5).

In $3.5 \%$ of the basin, residential, tourism, industry and mining activities are realized. Residential areas appear over $2^{\text {nd }}$, $6^{\text {th }}, 3^{\text {rd }}, 7^{\text {th }}, 4^{\text {th }}$, and $1^{\text {st }}$ class lands. Having witnessed to settlement for nearly 4000-5000 years, the Protection Basin of Tahtalı Dam has hosted 94.649 people by the year 2015. The Menderes county town (35.540 people), Sarnıç (25 427 people), Görece (7590 people), Tekeli (2823 people), Küner (2227 people), Develi (1994 people), Bulgurca (1821 people), Çileme (1790 people), Oğlananası (1782 people), Çamönü (1695 people), Değirmendere (1589 people), Kırıklar (1520 people) and Kaynaklar (1248 people) neighborhoods are important settlements in the basin (TÜIK, 2015). Settlement in the basin begins from the base of the basin and can be able to go up to 440m (Doğancılar Neighborhood). In the study area, it is seen that half of the settlements $(52 \%, 14$ settlements) appear on the base of the basin, 33\% (9 settlements) on the skirt plains, and $15 \%$ (4 settlements) on the mountain slopes.

Temporal change of land use (1990-2015) : Despite a $12 \%$ decrease (2410ha) in cropland areas and 1.4\% (588ha) in forest- 
Table 3: Temporal change of land use in the Protection Basin of Tahtalý Dam(1990-2015)

\begin{tabular}{|c|c|c|c|c|c|c|}
\hline \multirow{2}{*}{$\begin{array}{l}\text { Years } \\
\text { Land Classes }\end{array}$} & \multicolumn{2}{|c|}{1990} & \multicolumn{2}{|c|}{2015} & \multicolumn{2}{|c|}{ Change (1990-2015) } \\
\hline & ha & $\%$ & $\mathrm{Ha}$ & $\%$ & $\mathrm{Ha}$ & $\%$ \\
\hline Forest & $41.182,5$ & 63.75 & $40.594,64$ & 6.284 & $-587,86$ & -1.4 \\
\hline Arable land & $20.930,4$ & 32.4 & $18.520,82$ & 28.67 & $-2.409,58$ & -11.5 \\
\hline Greenhouse & 8,46 & 0 & $1.492,26$ & 2.31 & $1.483,8$ & 17.539 \\
\hline Settlement & $1.698,98$ & 2.63 & $2.267,46$ & 3.51 & 568,48 & 33.5 \\
\hline Water surfaces & 788,12 & 1.22 & $1.724,82$ & 2.67 & 936,7 & 118.9 \\
\hline
\end{tabular}

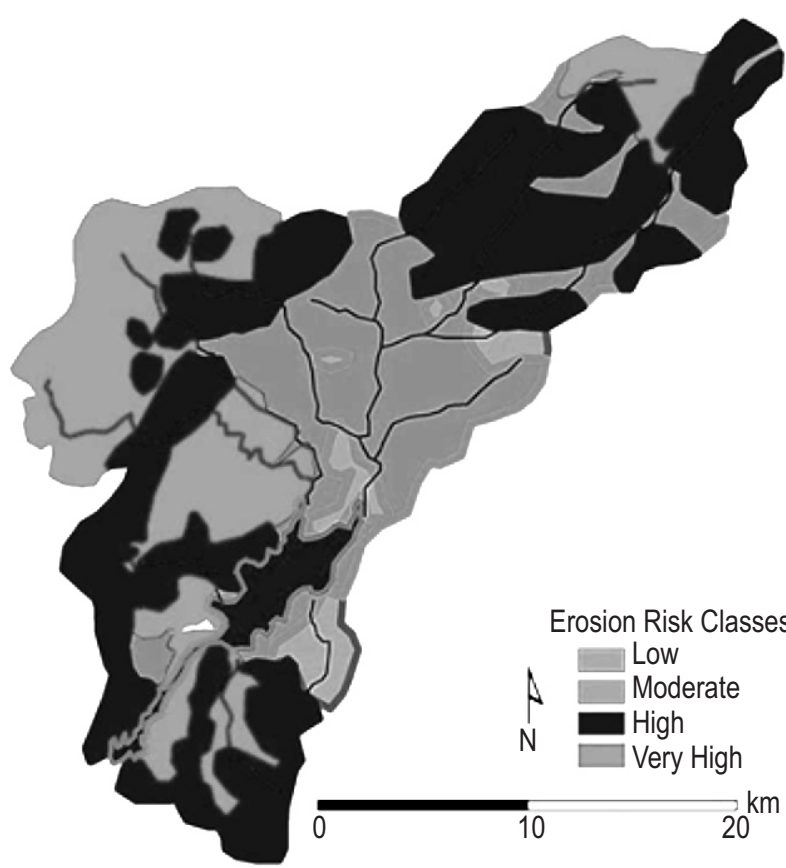

Fig. 5 : Erosion map in the Protection Basin of Tahtalı Dam

maquis areas, a $119 \%$ increase (938 ha) in water surfaces and $34 \%$ (569ha) in residential areas occurred through 1990-2015 in the Protection Basin of Tahtalı Dam (Table 3, Fig. 3 and 4). A $17539 \%$ increase (1484 ha) happened in greenhouse areas (in 1990 , only 8.46 ha, $0.01 \%$ ). Decrease in cropland areas is associated with the beginning of Tahtalı Dam to retain water (the year 1996) and expanding residential areas.

Decrease in forest-maquis areas is associated with intensive destruction by the people in the vicinity as well as the beginning of Tahtalı Dam to retain water (the year 1996) and expanding residential areas. Increase in greenhouse areas is due to promoting dry farming and green housing within the scope of protection activities. The increase in water surfaces is associated with occupying cropland, forest, and partly residential areas by dam's water along with beginning of Tahtalı Dam to retain water (1986-1996). Expansion in residential areas is related to the unearned income-purpose housing (number of illegal dwellinghouse is over 5000) and the construction of new industrialcommercial facilities, as well as increasing population through

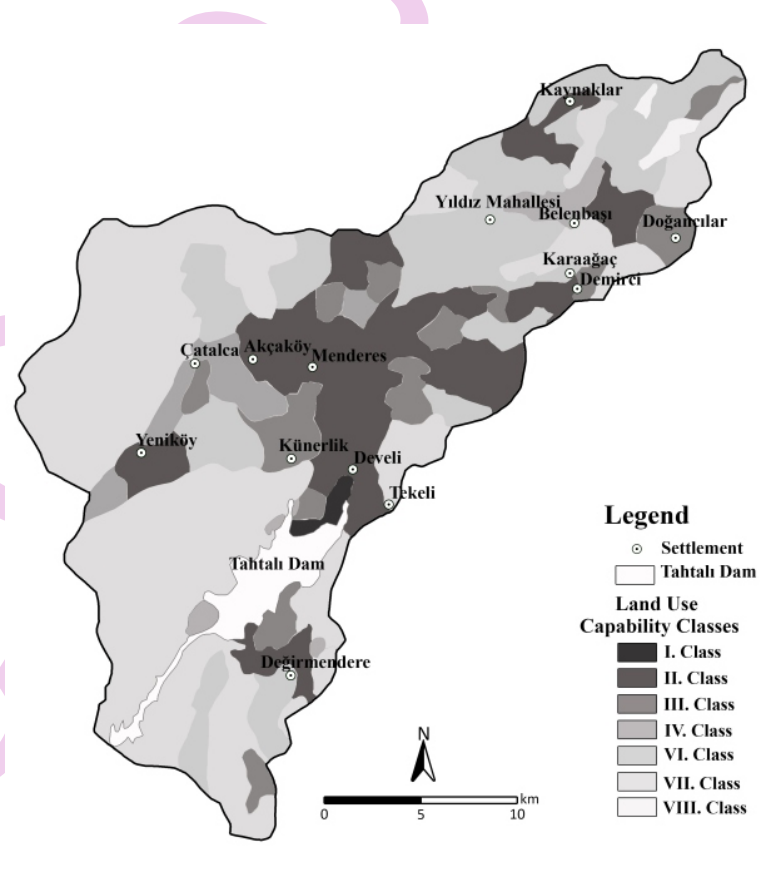

Fig. 6 : Map of land capability classes in the Protection Basin of Tahtalı Dam

birth and domestic migration. As a matter of fact, through 19902015 , population of the basin increased $129 \%$ (53.379 people).

This paper was aimed to evaluate temporal change of land use in the Protection Basin of Tahtalı Dam in terms of sustainable use of natural resources through 1990 and 2015. Despite a $12 \%$ decrease in cropland areas and $1.4 \%$ in forestmaquis areas, a $119 \%$ increase in water surfaces, $34 \%$ in residential areas and $17539 \%$ in greenhouse areas occurred through 1990-2015 in the Protection Basin of Tahtalı Dam.

There is a mismatch between the land capability classes and their use (Fig. 4 and 6). Indeed, in the basin, agriculture (18\%) has been carried out in non-arable $6^{\text {th }}, 7^{\text {th }}$, and $7^{\text {th }}$ class lands and there have been settlement areas $(2 \%)$. Some part of arable lands of $1^{\text {st }}, 2^{\text {nd }}$, and $3^{\text {rd }}$, and $6^{\text {th }}$ has been used as settlement areas. Four per cent of $1^{\text {st }}, 2^{\text {nd }}$, and $3^{\text {rd }}$, and $6^{\text {th }}$ class lands submerged under the dam's water. The said situation has resulted in some disadvantages. As a matter of fact, severe erosion which is seen at the part of $54 \%$ of the basin has the impact on lands which are 
inclined and devoid of natural vegetation cover (Fig. 5). There is an increase stemming from domestic and industrial wastes in Parameters for Chemical Oxygen Demand and Biological Oxygen Demand in the basin (Selçuk and Elçi, 2008). As a result of land degradation and erosion, nearly $25 \%$ of lands of the basin have become unusable losing their natural characteristics.

In order to prevent degradation, erosion, and pollution, soils should be used according to the land capability classes (Atalay and Gündüzoğlu, 2015). In the basin, agriculture of xeromorphic species which consume less water instead of those which need plenty of water should be carried out (Fig. 6). Chemical fertilizer/insecticide use in agricultural areas, industrial facilities and development of canals\&sewages to the dam through rivulets, including the Menderes county town, which all are essential pollutant elements of the dam's water, should be prevented. Cooperativation should be encouraged for a continuous and the planned marketing in the basin (Gülersoy, Gümüş and IIlhan, 2014), and alternative sustainable economic activities should be promoted. Furthermore, basin protection activities should be formed by an interdisciplinary understanding and collaboration should be established among local people.

\section{References}

Atalay, I. and R. Efe: Structural and distributional evaluation of forest ecosystems in Turkey. J. Environ. Biol., 31, 61-70 (2010).

Atalay, I. and A.G. Gündüzoğlu: Land capability classification according to ecological conditions of Turkey, Meta Press, Izmir, Turkey (2015).

Barış, N.: Investigation of hydrogeology and evaluation of groundwater contamination using AHS-DRASTIC Method in Tahtalı dam basin. Unpublished PhD dissertation.Dokuz Eylul University, Institute of Science. Izmir, Turkey (2008).

Buca, Gaziemir, Menderes, Torbalı district Agriculture Directorates: Agricultural data of Buca, Gaziemir, Menderes, Torbalı districts. Izmir, Turkey (1990).

Buca, Gaziemir, Menderes, Torbalı district Agriculture Directorates: Agricultural data of Buca, Gaziemir, Menderes, Torbalı districts. Izmir, Turkey (2015).

Efe, R., A. Soykan, İ. Cürebal and S. Sönmez: Land use and land cover detection in Karinca River Catchment (NW Turkey) using GIS and RS Techniques. J. Environ. Biol., 33, 439-447 (2012).

Efe, R., A. Soykan, I. Cürebal and S. Sönmez: Olive and olive oil in the world, Turkey, in and around Edremit Gulf. $2^{\text {nd }}$ Edn., Akmat Press. ISBN: 978-605-62253-0-7 (2013).

Feoli, E., P. Giacomich, K. Mignozzi, M. Öztürk and M. Scimone: Monitoring desertification risk with an index integrating climatic and remotely-sensed data: An example from the coastal area of Turkey. Manag. Environ. Qual.: An Int. J., 14, 10-21 (2003).

Ghimire, B. K. and M.P. Pimbert (Ed.): Social Change and Conservation, Earthscan Publications Limited, United Kingdom (1997).

Goudie, A.: The human Impact on the natural environment. Blackwell Publishers, Oxford (2006)

Gülersoy, A.E.: Temporal change of land use activities around immediate surroundings of lake Marmara (1975-2011) and its effects on Lake Ecosystem. Turkish Geographical Review, 61, 36-37 (2013).

Gülersoy, A.E., N. Gümüş and A. Illhan: From tradition to modernity, from the field to the theater; A Transformation Story: Bademler Village (Izmir). TUCAUM VIII. Geography Symposium. Proceedings, Ankara, pp. 438-448 (2014).

Gülersoy, A.E., N. Gümüş, M.E. Sönmez and G. Gündüzoğlu: Relations between the land use and land capability classification in Küçük Menderes River Basin, J. Environ. Biol., 36, 17-26 (2015).

Gülersoy, A.E., M.A. Çelik: Determining of areas with high erosion risk in Küçük Menderes River Basin (West Anatolia, Turkey) by using multi-criteria decision making method. Fres. Environ. Bull., 24, 195-202 (2015).

IZSU (Izmir Water and Sewerage Administration General Directorate): Protection Basin of Tahtalı Dam. Izmir (2016).

Koçman, A.: Researches and applied physical geography studies in Izmir-Bozdaglar region. Ege University, Faculty of Letters, Izmir (1989).

Manyari, W.V. and O.A. Carvalho: Environmental considerations in energy planning for the Amazon Region: Downstream effects of Dams. Energy Policy, 35, 6526-6534 (2007).

Öztürk, M., A. Celik, C. Yarci, A. Aksoy and E. Feoli: An overview of plant diversity, land use and degradation in the Mediterranean region of Turkey. Environ. Manag. Hlth., 13, 442-449 (2002).

Selçuk, P. and Ş. Elçi: Analysis of effects of land use on water quality in Tahtalı River Basin. DSI II., District Directorate, Izmir. Basin Pollution Conference Proceedings, pp. 73-88 (2008).

Sönmez, M.E.: Negative effects of dams on space: Cases from Turkey. Gaziantep University. J. Social Sci., 11, 213-231 (2012).

Strahler, A. and A. Strahler: Introducing physical geography. John Wiley \& Sons Publishing, New York, USA(2006).

TÜiK: Bulletin of address based population census results for 1990 . Ankara (1990).

TÜIK: Bulletin of address based population census results for 2015 . Ankara (2015). 